\title{
Silicate solution, cation properties, and mass transfer by aqueous fluid in the Earth's interior
}

\author{
Bjorn Mysen (1)
}

\begin{abstract}
Aqueous fluids in the Earth's interior are multicomponent systems with silicate solubility and solution mechanisms strongly dependent on other dissolved components. Here, solution mechanisms that describe the interaction between dissolved silicate and other solutes were determined experimentally to $825^{\circ} \mathrm{C}$ and above $1 \mathrm{GPa}$ with in situ vibrational spectroscopy of aqueous fluid while these were at high temperature and pressure. The silicate content in Na-bearing, silicate-saturated aqueous fluid exceeds that in pure $\mathrm{SiO}_{2}$ at high temperature and pressure. Silicate species were of $\mathrm{Q}^{0}$ (isolated $\mathrm{SiO}_{4}$ tetrahedra) and $\mathrm{Q}^{1}$ (dimers, $\mathrm{Si}_{2} \mathrm{O}_{7}$ ) type. The temperature dependence of its equilibrium constant, $K=X_{\mathrm{Q}_{1}} /\left(X_{\mathrm{QO}_{0}}\right)^{2}$, yields enthalpies of $22 \pm 12$ and $51 \pm 17 \mathrm{~kJ} / \mathrm{mol}$ for the $\mathrm{SiO}_{2^{-}}$ $\mathrm{H}_{2} \mathrm{O}$ and Na-bearing fluids. In contrast, in Ca-bearing fluids, the solubility is more than an order of magnitude lower, and only $\mathrm{Q}^{0}$ species are present. The present data together with other published experimental information lead to the conclusion that the silicate solubility in aqueous fluids in equilibrium with mafic rocks such as amphibolite and peridotite is an order of magnitude lower than the solubility in fluids in equilibrium with felsic rocks such as andesite and rhyolite compositions (felsic gneiss) under similar temperature and pressure conditions. The silicate speciation also is more polymerized in the felsic systems. This difference is also why second critical end-points in the Earth are at lower temperature and pressure in felsic compared with mafic systems. Alkali-rich fluids formed by dehydration of felsic rocks also show enhanced high field strength element (HFSE) solubility because alkalis in such solution form oxy complexes with the HFSE cations. Fluids formed by dehydration of felsic rocks in the Earth's interior are, therefore, more efficient transport agents of silicate materials than fluids formed by dehydration of mafic and ultramafic rocks, whether for major, minor, or trace elements.
\end{abstract}

Keywords: Aqueous fluid, Solubility, Structure, Spectroscopy, Silicate

\section{Introduction}

The solubility and solution mechanism(s) of silicate components in aqueous fluids in the Earth's interior are central to our understanding of the roles of aqueous fluids in material transport within the Earth (Fockenberg et al. 2006; Newton and Manning 2009; Burchard et al. 2011). This is particularly so in and near subduction zones where water-rich fluids released from dehydrating slab materials can transport chemical components into source regions of melting and, at the same time, deplete dehydrating slab materials of fluid-soluble components (Mibe et al. 2008; Kawamoto et al. 2012). In this environment, hydrated rocks ranging from amphibolite and peridotite to felsic

Correspondence: bmysen@carnegiescience.edu

Geophysical Laboratory, Carnegie Institution of Washington, Washington, DC, USA gneiss compositions are subjected to dehydration and release of silicate-saturated water-rich fluids.

The abundance of components known to affect silicate solubility in aqueous fluid differs significantly among those rock types in the Earth's interior. It is necessary, therefore, to determine how individual compositional variables affect the silicate solubility and structure of dissolved silicate in aqueous fluids at relevant high-temperature and high-pressure conditions.

Composition and structure of silicate-saturated aqueous fluids at high temperature and pressure have been determined experimentally for pure $\mathrm{SiO}_{2}-\mathrm{H}_{2} \mathrm{O}$ systems as well as for some more complex silicate and aluminosilicate compositions (Newton and Manning 2002; Kessel et al. 2005; Mibe et al. 2008, 2011; Mysen 2010). From those 
experiments, it is evident that silicate solubility in aqueous fluids depends on the presence of other components in addition to $\mathrm{SiO}_{2}$. In the $\mathrm{MgO}-\mathrm{SiO}_{2}-\mathrm{H}_{2} \mathrm{O}$ system, for example, the solubility in the aqueous fluid decreases with increasing $\mathrm{Mg} / \mathrm{Si}$ abundance ratio (Zhang and Frantz 2000). Addition of aluminosilicate components to $\mathrm{SiO}_{2}$ also enhances the solubility in fluid (Wilke et al. 2012). However, quantitative characterization of how individual components affect silicate solubility and solution mechanisms of other components in aqueous fluids is not well developed.

Determination of fluid composition and structure at temperature and pressure conditions of the deep crust, upper mantle, and beyond is challenging because silicate-saturated fluids commonly do not retain in solution the chemical components and the fluid structure that existed at the high temperature and pressure after temperature quenching from experimental conditions to ambient temperature and pressure. Various methods have been proposed with which to overcome these obstacles. For example, Kessel et al. (2004) described a method whereby fluids were soaked into layers of pore space among diamond particles during experiments. Analysis of these diamond aggregates after termination of an experiment provided the fluid data. Others rely on accurate weighing of crystals from the experimental charges before and after an experiment at high temperature and pressure during which crystalline material equilibrated with fluid (Manning and Boettcher 1994). The weight difference is the weight of the solute.

An alternative, which does not rely on quenching to ambient conditions before analysis, is to conduct structural characterization of fluids in the equilibrium with one or more condensed phases while at the temperatures and pressures of interest. This can be accomplished with the sample contained in an externally heated hydrothermal diamond anvil cell (Bassett et al. 1993). Here, this experimental protocol was employed to assess the influence of alkalis and alkaline earth cations on $\mathrm{SiO}_{2}$ solubility in aqueous solutions to temperatures and pressures corresponding to the deep crust and upper mantle.

\section{Methods/Experimental}

Three different starting materials were used. Those were crystalline quartz $+\mathrm{H}_{2} \mathrm{O}$, crystalline quartz $+0.7 \mathrm{~m} \mathrm{NaOH}$ aqueous solution, and an $\mathrm{SiO}_{2}+\mathrm{CaO}$ mixture $+\mathrm{H}_{2} \mathrm{O}$ $\left(\mathrm{SiO}_{2}: \mathrm{CaO}=9: 1\right.$ by mol). By using $\mathrm{NaOH}$ as the $\mathrm{Na}^{+}$-bearing fluid component, it cannot be ruled out that an increased $\mathrm{pH}$ compared with pure $\mathrm{H}_{2} \mathrm{O}$ could also affect the silicate solubility in the fluid.

The $\mathrm{CaO}-\mathrm{SiO}_{2}$ material was prepared by melting at ambient pressure at $1725{ }^{\circ} \mathrm{C}$ followed by crystallization at $1500{ }^{\circ} \mathrm{C}$. At $1725^{\circ} \mathrm{C}$, this system comprises immiscible silicate liquids (Osborn and Muan 1960). In order to form the crystalline $\mathrm{SiO}_{2}$ component desired to equilibrate with fluid, the crystallization step at $1500{ }^{\circ} \mathrm{C}$ was performed. This mixture, consisting of crystalline tridymite + glass (Ca-rich) was used together with $\mathrm{H}_{2} \mathrm{O}$ as a starting material. During the experiments, tridymite converted to quartz and glass to wollastonite, as discussed further below.

The experiments were carried out in an externally heated, hydrothermal diamond anvil cell (HDAC) of the design originally described by Bassett et al. (1993). In the HDAC, the sample was heated with external heaters. These heaters were comprised of Mo wire wrapped around the $\mathrm{SiC}$ diamond seats of upper and lower diamonds that were held in place with alumina high-temperature cement. Iridium gaskets ( $125 \mu \mathrm{m}$ thick) with a $500-\mu \mathrm{m}$ sample hole were employed for sample containment. During an experiment, the gaskets shrunk to about $80 \mu \mathrm{m}$ thickness and the hole to $\sim 400 \mu \mathrm{m}$ diameter.

MicroRaman spectroscopy and optical microscopy were used to characterize the samples while these were in the $\mathrm{HDAC}$ at the pressure/temperature of interest. The Raman system is a JASCO model NRS-3100 confocal microRaman spectrometer with a single monochromator and holographic gratings (1200 and 2400 grooves $/ \mathrm{mm})$. A long working distance $(25 \mathrm{~mm}), \times 50$ magnification, 0.42 N.A. objective lens was used in this design, which provided a better than $5 \mu \mathrm{m}$ spatial resolution for sample examination and spectroscopic characterization. The sampling depth was about $30 \mu \mathrm{m}$ (Mysen 2015a). The signals were recorded with an Andor ${ }^{\mathrm{rm}}$ Model DV401-F1 $1024 \times 28$ pixel Peltier-cooled CCD (charge-coupled detector). Energy resolution was $\pm 3 \mathrm{~cm}^{-1}$ with 1200 grooves/mm gratings, whereas with 2400 grooves $/ \mathrm{mm}$, spectral reproducibility was about $1 \mathrm{~cm}^{-1}$.

Temperatures in the diamond cell were monitored with two K-type thermocouples that touched the diamonds at a $\sim 1$-mm distance from the sample chamber. A feedback mechanism was utilized for temperature control. Temperature precision was $\pm 1{ }^{\circ} \mathrm{C}$, whereas the uncertainty, determined against the melting point of $\mathrm{NaCl}$, was $2-3{ }^{\circ} \mathrm{C}$. The gasket hole in the Ir gasket material deformed some during the experiments, which were not, therefore, strictly isochoric. Pressure could not, therefore, be calculated from the PVT data of pure $\mathrm{H}_{2} \mathrm{O}$. Furthermore, silicate components dissolved in the fluid also affect the equation of state of $\mathrm{H}_{2} \mathrm{O}$ (Mysen 2010). Instead, the pressure was measured with the one-phonon Raman line from a chip of synthetic carbon-13 diamond placed inside the sample chamber. From this information, the pressure was determined with the calibration of Mysen and Yamashita (2010). An internal standard of $\mathrm{Ne}$ emission lines was employed to optimize the energy resolution. With this standard 
together with 2400 grooves $/ \mathrm{mm}$ gratings, a frequency uncertainty of $\pm 0.1 \mathrm{~cm}^{-1}$ was obtained. This uncertainty translates to a pressure precision of $\pm 40 \mathrm{MPa}$. However, the overall pressure uncertainty is approximately $\pm 110 \mathrm{MPa}$ when taking into considerations the uncertainties in the pressure calibration by Mysen and Yamashita (2010).

Several series of measurements at different temperatures and pressures were carried out with the three different starting materials such that for each of the three starting compositions, the sample was first taken to the highest planned temperature and pressure and left there for an hour before spectroscopic measurements. The sample was then cooled at $1{ }^{\circ} \mathrm{C} / \mathrm{s}$ in $50-75{ }^{\circ} \mathrm{C}$ intervals to the next temperature and pressure condition where the spectra were recorded after about 60 -minute dwell time. With this sample configuration, the 60-minute dwell time is sufficient to reach equilibrium (Mysen 2015b).

\section{Results}

Quartz and aqueous fluid were present in all experiments (Table 1). Additionally, in the system $\mathrm{SiO}_{2}-\mathrm{CaO}-$ $\mathrm{H}_{2} \mathrm{O}$, wollastonite coexists with quartz and fluid (Fig. 1). The quartz and wollastonite, identified from their Raman spectra, grew from the starting materials during the initial hour at the highest temperature and pressure. The high-temperature spectra typically are broader and less well resolved compared with the spectra recorded at ambient temperature and pressure (Fig. 2).

The spectra of silicates and fluid at high temperature and pressure show Raman signals in a high-frequency region centered between 3500 and $3600 \mathrm{~cm}^{-1}$ and a low-frequency region between 300 and $1200 \mathrm{~cm}^{-1}$. The high-frequency region comprises that of the fundamental $\mathrm{O}-\mathrm{H}$ vibrations in $\mathrm{OH}$ groups, whether in molecular $\mathrm{H}_{2} \mathrm{O}$ or as $\mathrm{OH}$ groups that form bonding with metal cations (Ratcliffe and Irish 1982; Walrafen et al. 1986). The low-frequency region, between about 300 and $1200 \mathrm{~cm}^{-1}$, includes the Raman bands assigned to vibrations in $\mathrm{Si}-\mathrm{O}$, $\mathrm{Al}-\mathrm{O}$, and metal oxide components (Brawer and White 1975; McMillan et al. 1992).

The high-frequency region comprises a single slightly asymmetric band. The asymmetry is less pronounced in the spectra from fluid in $\mathrm{SiO}_{2}-\mathrm{CaO}-\mathrm{H}_{2} \mathrm{O}$ than for the other two compositions (Fig. 3). The low-frequency region characteristically has a strong and sharp band between 770 and $800 \mathrm{~cm}^{-1}$ (Fig. 4). In the $\mathrm{SiO}_{2}-\mathrm{CaO}-\mathrm{H}_{2} \mathrm{O}$ fluid spectra, this is the only Raman band in this frequency region (Fig. 4c), whereas for $\mathrm{SiO}_{2}-\mathrm{H}_{2} \mathrm{O}$ and $\mathrm{SiO}_{2}-\mathrm{NaOH}-\mathrm{H}_{2} \mathrm{O}$ fluids, there is a Raman intensity on both the low- and high-frequency side of $770-800 \mathrm{~cm}^{-1}$ peak (Fig. 4a, b). These latter intensities are strongest in the spectra of $\mathrm{SiO}_{2}-\mathrm{NaOH}-\mathrm{H}_{2} \mathrm{O}$ fluids (Fig. 4b). The intensity of all bands grows with the increasing temperature and pressure.

The $770-800 \mathrm{~cm}^{-1}$ band is assigned to $\mathrm{Si}-\mathrm{O}^{-}$stretch vibrations in isolated $\mathrm{SiO}_{4}$ tetrahedra $\left(\mathrm{Q}^{0}\right.$ species $)$ with one or more of the nonbridging oxygens forming bonds with $\mathrm{H}^{+}$(Zotov and Keppler 2002; Mibe et al. 2008). This is the same vibration as that gives rise to a $850 \mathrm{~cm}^{-1}$ Raman band in anhydrous silicate melts and glasses (see review of Raman band assignments in such systems by Mysen and Richet 2005). The lower frequency of the $\mathrm{Si}-\mathrm{O}^{-}$stretch vibration in hydrous melts is because of the much smaller radius of $\mathrm{H}^{+}$bonded to nonbridging oxygens in the structure compared with alkali metals and alkaline earths. Raman intensity at a higher frequency, as observed in the spectra of $\mathrm{SiO}_{2}-\mathrm{H}_{2} \mathrm{O}$ and $\mathrm{SiO}_{2}-\mathrm{NaOH}-\mathrm{H}_{2} \mathrm{O}$ fluid, is assigned to $\mathrm{Si}-\mathrm{O}^{-}$vibrations in silicate species more polymerized than isolated $\mathrm{SiO}_{4}$ groups. Most likely, these are species with one bridging oxygen ( $\mathrm{Q}^{1}$ species) (Mysen et al. 2013). Bending vibrations of such a bridge give rise to the intensity centered near $600 \mathrm{~cm}^{-1}$.

It follows, therefore, that for fluids in equilibrium with quartz in the system $\mathrm{SiO}_{2}-\mathrm{NaOH}-\mathrm{H}_{2} \mathrm{O}$, the silicate polymerization with $\mathrm{Q}^{0}$ and $\mathrm{Q}^{1}$ species is similar

Table 1 Run data

\begin{tabular}{|c|c|c|c|c|c|c|c|c|}
\hline \multicolumn{3}{|l|}{$\mathrm{SiO}_{2}-\mathrm{H}_{2} \mathrm{O}$} & \multicolumn{3}{|c|}{$\mathrm{SiO}_{2}-\mathrm{NaOH}-\mathrm{H}_{2} \mathrm{O}$} & \multicolumn{3}{|c|}{$\mathrm{SiO}_{2}-\mathrm{CaO}-\mathrm{H}_{2} \mathrm{O}$} \\
\hline$\overline{\operatorname{Temp}\left({ }^{\circ} \mathrm{C}\right)^{\mathrm{a}}}$ & Press $(\mathrm{MPa})^{\mathrm{b}}$ & Phases & $\overline{\operatorname{Temp}}\left({ }^{\circ} \mathrm{C}\right)$ & Press (MPa) & Phases & $\overline{T e m p}\left({ }^{\circ} \mathrm{C}\right)$ & Press (MPa) & Phases \\
\hline 25 & 0.1 & Qtz + fluid & 25 & 0.1 & Qtz + fluid & 25 & 0.1 & $\mathrm{Qtz}+$ Wo + fluid \\
\hline 550 & 391 & Qtz + fluid & 550 & 583 & Qtz + fluid & 575 & 396 & Qtz + Wo + fluid \\
\hline 625 & 542 & Qtz + fluid & 625 & 638 & Qtz + fluid & 625 & 468 & Qtz + Wo + fluid \\
\hline 700 & 696 & Qtz + fluid & 700 & 851 & Qtz + fluid & 675 & 498 & $\mathrm{Qtz}+$ Wo + fluid \\
\hline 775 & 956 & Qtz + fluid & 775 & 1012 & Qtz + fluid & 725 & 709 & Qtz + Wo + fluid \\
\hline \multirow[t]{2}{*}{800} & 725 & Qtz + fluid & 800 & 1134 & Qtz + fluid & 775 & 952 & Qtz + Wo + fluid \\
\hline & & & & & & 825 & 933 & $\mathrm{Qtz}+$ Wo + fluid \\
\hline
\end{tabular}

${ }^{\mathrm{a}}$ Temperature uncertainty, $2-3{ }^{\circ} \mathrm{C}$

${ }^{\mathrm{b}}$ Pressure uncertainty, $\pm 110 \mathrm{MPa}$ 

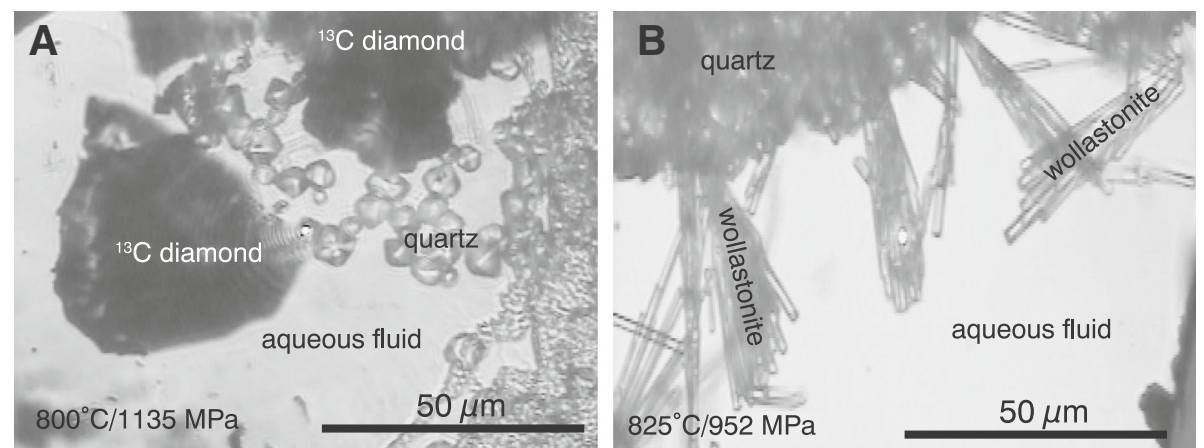

Fig. 1 Examples of microphotographs of samples in the hydrothermal diamond anvil cell at high temperature and pressure. a View of the sample from $\mathrm{SiO}_{2}-\mathrm{NaOH}-\mathrm{H}_{2} \mathrm{O}$ at $800{ }^{\circ} \mathrm{C}$ and $1135 \mathrm{MPa}$. b View of the sample from $\mathrm{SiO}_{2}-\mathrm{CaO}-\mathrm{H}_{2} \mathrm{O}$ at $825^{\circ} \mathrm{C}$ and $925 \mathrm{MPa}$

to that in $\mathrm{SiO}_{2}-\mathrm{H}_{2} \mathrm{O}$ fluid spectra at higher pressures (Mysen et al. 2013). It also resembles the aqueous fluids in the equilibrium with alkali aluminosilicate melt under similar temperature and pressure conditions (Mysen 2010).

\section{Discussion}

The Raman spectra indicate that the silicate concentration and speciation in the fluid at given temperature and pressure is dependent on the nature of the crystalline materials in the equilibrium with the fluid.

\section{Solubility}

Silicate solubility in the aqueous fluids might be estimated by combining silica solubility in the fluid in the system $\mathrm{SiO}_{2}-\mathrm{H}_{2} \mathrm{O}$ (Manning 2004) with the intensity of relevant Raman bands in order to generate a calibration curve from the intensity of Raman bands in spectra of

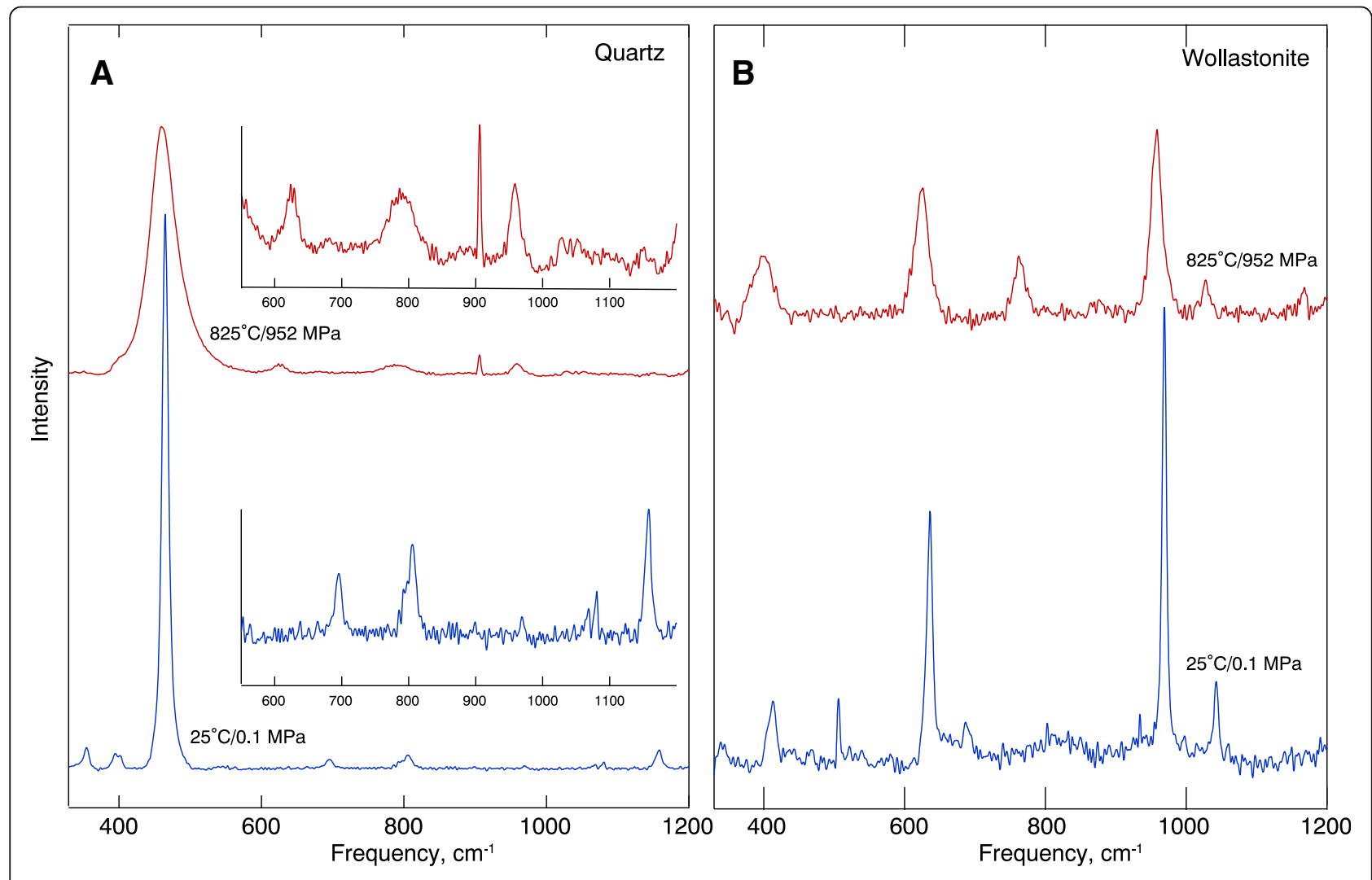

Fig. 2 Raman spectra of crystalline quartz (a) and wollastonite (b) from the system $\mathrm{SiO}_{2}-\mathrm{CaO}-\mathrm{H}_{2} \mathrm{O}$ at $825^{\circ} \mathrm{C} / 952 \mathrm{MPa}$ and ambient conditions 


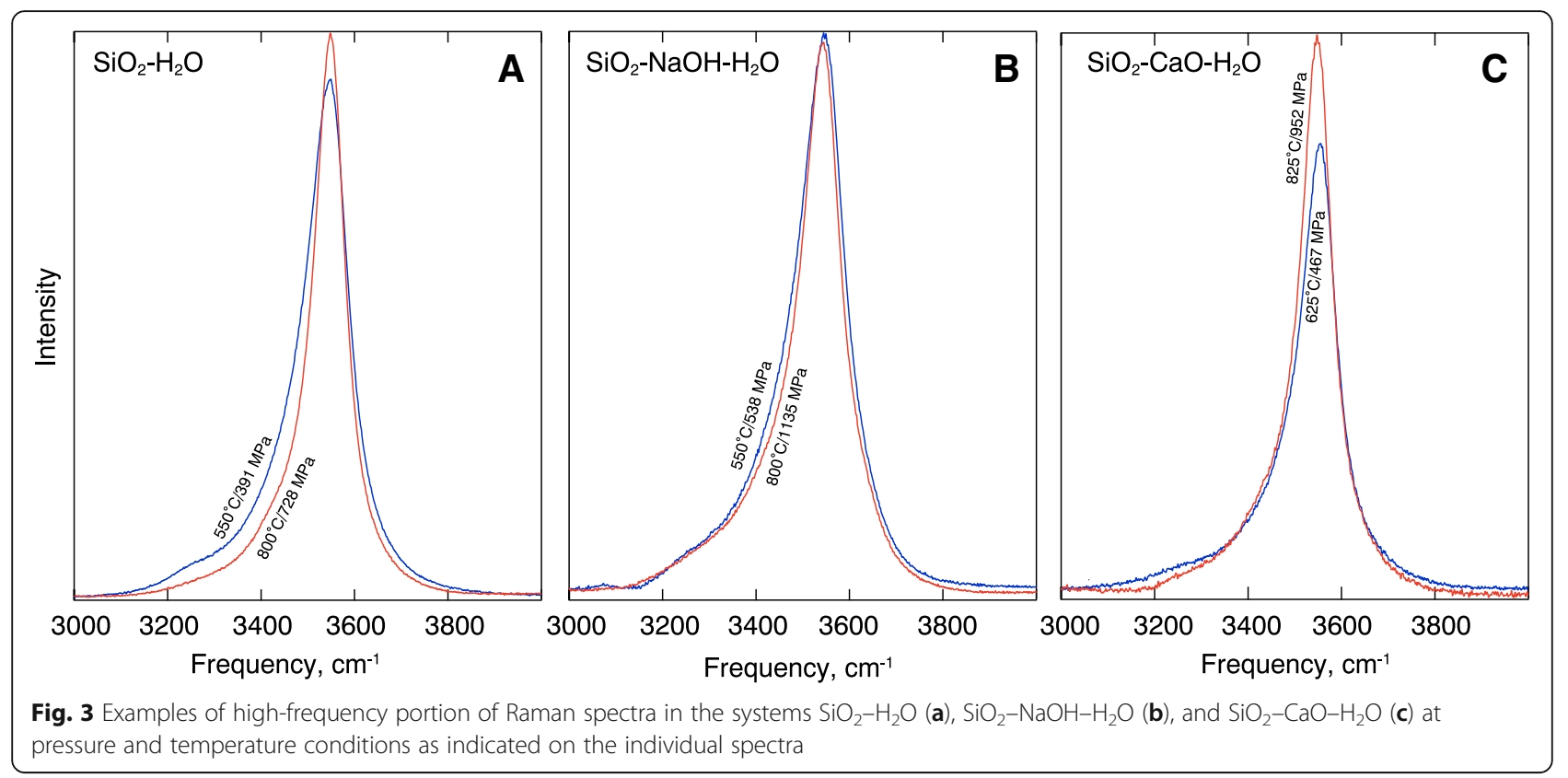

fluid. This calibration curve then may be used to compute an approximate solubility of $\mathrm{SiO}_{2}$ in the fluids from the other two series of experiments $\left(\mathrm{SiO}_{2}-\mathrm{NaOH}-\mathrm{H}_{2} \mathrm{O}\right.$ and $\mathrm{SiO}_{2}-\mathrm{CaO}-\mathrm{H}_{2} \mathrm{O}$ ).

The silicate contents of fluid in equilibrium with quartz in the $\mathrm{SiO}_{2}-\mathrm{H}_{2} \mathrm{O}$ system were calculated with the algorithm of Manning (1994) in which the temperature and the density of pure $\mathrm{H}_{2} \mathrm{O}$ are variables. For the density of the fluid, the calculations by Withers, using the formulism of Pitzer and Sterner (1994), were employed [URL: https://www.esci.umn.edu/ people/researchers/withe012/fugacity.htm]. Those $\mathrm{SiO}_{2}$ solubilities (Table 2) were then used to create a calibration curve based on the $770+850 \mathrm{~cm}^{-1}$ integrated Raman intensities from the fluid spectra (see Fig. 4). The data points defining the solubility relations were fitted to the function (Fig. 5):

$$
\log m_{\mathrm{SiO} 2}(\mathrm{~mol} / \mathrm{kg})=1.6-2.0 \cdot \operatorname{Int}^{-0.32}(\mathrm{cts} / \mathrm{s}),
$$

where "Int" is the integrated intensity of the $770+$ $850 \mathrm{~cm}^{-1}$ Raman bands in counts per second, and $m_{\mathrm{SiO} 2}$ is silica molality.

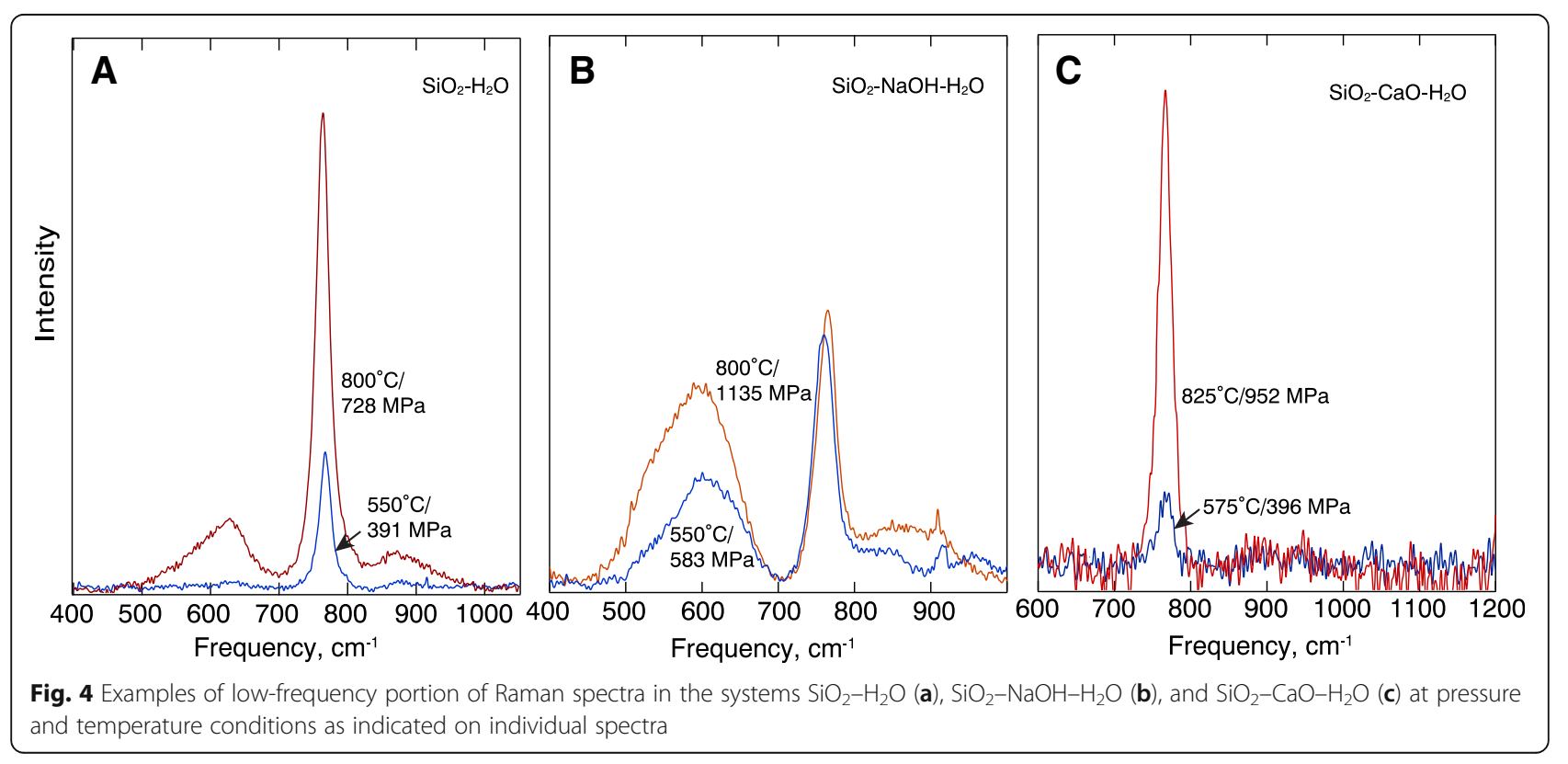


Table 2 Solubility data

\begin{tabular}{|c|c|c|c|c|}
\hline \multicolumn{5}{|l|}{$\mathrm{SiO}_{2}-\mathrm{H}_{2} \mathrm{O}$} \\
\hline Temp $\left({ }^{\circ} \mathrm{C}\right)$ & Press (MPa) & Density $\left(\mathrm{g} / \mathrm{cm}^{3}\right)$ & $f_{\mathrm{H} 2 \mathrm{O}}(\mathrm{MPa})$ & $\begin{array}{l}\mathrm{SiO}_{2} \text { solubility, } \\
m_{\mathrm{SiO} 2}(\mathrm{~kg} / \mathrm{mol})^{\mathrm{a}}\end{array}$ \\
\hline 800 & 728 & 0.794 & 852 & 0.0304 \\
\hline 775 & 956 & 0.876 & 1440 & 0.0273 \\
\hline 700 & 696 & 0.831 & 668 & 0.0082 \\
\hline 625 & 542 & 0.813 & 364 & 0.0022 \\
\hline 550 & 391 & 0.789 & 178 & 0.0004 \\
\hline \multicolumn{5}{|c|}{$\mathrm{SiO}_{2}-\mathrm{NaOH}-\mathrm{H}_{2} \mathrm{O}$} \\
\hline Temp $\left({ }^{\circ} \mathrm{C}\right)$ & Press (MPa) & Density $\left(\mathrm{g} / \mathrm{cm}^{3}\right)$ & $f_{\mathrm{H}_{2} \mathrm{O}}(\mathrm{MPa})$ & $\begin{array}{l}\mathrm{SiO}_{2} \text { solubility, } \\
m_{\mathrm{SiO} 2}(\mathrm{~kg} / \mathrm{mol})^{\mathrm{b}}\end{array}$ \\
\hline 800 & 1135 & 0.911 & 1978 & 0.0238 \\
\hline 775 & 1012 & 0.891 & 1642 & 0.0448 \\
\hline 700 & 851 & 0.88 & 999 & 0.0288 \\
\hline 550 & 583 & 0.871 & 328 & 0.0092 \\
\hline \multicolumn{5}{|c|}{$\mathrm{SiO}_{2}-\mathrm{CaO}-\mathrm{H}_{2} \mathrm{O}$} \\
\hline Temp $\left({ }^{\circ} \mathrm{C}\right)$ & Press (MPa) & Density $\left(\mathrm{g} / \mathrm{cm}^{3}\right)$ & $f_{\mathrm{H} 2 \mathrm{O}}(\mathrm{MPa})$ & $\begin{array}{l}\mathrm{SiO}_{2} \text { solubility, } \\
m_{\mathrm{SiO} 2}(\mathrm{~kg} / \mathrm{mol})^{\mathrm{b}}\end{array}$ \\
\hline 575 & 396 & 0.775 & 198 & 4.86525E-08 \\
\hline 625 & 468 & 0.779 & 291 & $1.43231 \mathrm{E}-07$ \\
\hline 675 & 498 & 0.764 & 362 & 1.38469E-05 \\
\hline 725 & 709 & 0.824 & 723 & 9.61047E-05 \\
\hline 775 & 953 & 0.875 & 1430 & 0.000369701 \\
\hline 825 & 933 & 0.849 & 1444 & 0.000506355 \\
\hline
\end{tabular}

${ }^{a}$ Calculations using the formalism from Manning (1994)

${ }^{\mathrm{b}}$ See text for calculations

The $\mathrm{SiO}_{2}$ solubility in the $\mathrm{SiO}_{2}-\mathrm{NaOH}-\mathrm{H}_{2} \mathrm{O}$ and $\mathrm{SiO}_{2}-$ $\mathrm{CaO}-\mathrm{H}_{2} \mathrm{O}$ fluids was then derived from the calibration curve in Fig. 6 and the integrated Raman intensities at $770+850 \mathrm{~cm}^{-1}$ from the $\mathrm{SiO}_{2}-\mathrm{NaOH}-\mathrm{H}_{2} \mathrm{O}$ and $\mathrm{CaO}-$ $\mathrm{SiO}_{2}-\mathrm{H}_{2} \mathrm{O}$ fluid spectra. In doing this, it was assumed that the different cations, $\mathrm{H}^{+}, \mathrm{Na}^{+}$, and $\mathrm{Ca}^{2+}$, in the aqueous solutions had no effect on the Raman intensities and that possible temperature and pressure effects in the pressure range under study on Raman intensity can be ignored.

With the above caveats in mind, the $\mathrm{SiO}_{2}$ solubility in $\mathrm{SiO}_{2}-\mathrm{CaO}-\mathrm{H}_{2} \mathrm{O}$ fluids from the calibration curve in Fig. 6 is an order of magnitude, or more, lower than in the $\mathrm{SiO}_{2}-\mathrm{NaOH}-\mathrm{H}_{2} \mathrm{O}$ and $\mathrm{SiO}_{2}-\mathrm{H}_{2} \mathrm{O}$ fluids in the $f_{\mathrm{H} 2 \mathrm{O}}$ $\left(\mathrm{H}_{2} \mathrm{O}\right.$ fugacity) range defined by the temperature and pressure conditions of these experiments (Fig. 6; Table 2). The solubility difference does, however, decrease with increasing fugacity of $\mathrm{H}_{2} \mathrm{O}$.

The significant solubility depression resulting from $10 \mathrm{~mol} \% \mathrm{CaO}$ to $\mathrm{SiO}_{2}$ appears similar to that from $\mathrm{MgO}$ in the system $\mathrm{MgO}-\mathrm{SiO}_{2}-\mathrm{H}_{2} \mathrm{O}$ (Zhang and Frantz 2000). This effect contrasts with adding $\mathrm{NaOH}$ where, despite the dilution of $\mathrm{SiO}_{2}$ concentration, the $\mathrm{SiO}_{2}$ solubility in aqueous fluids is similar to that in the
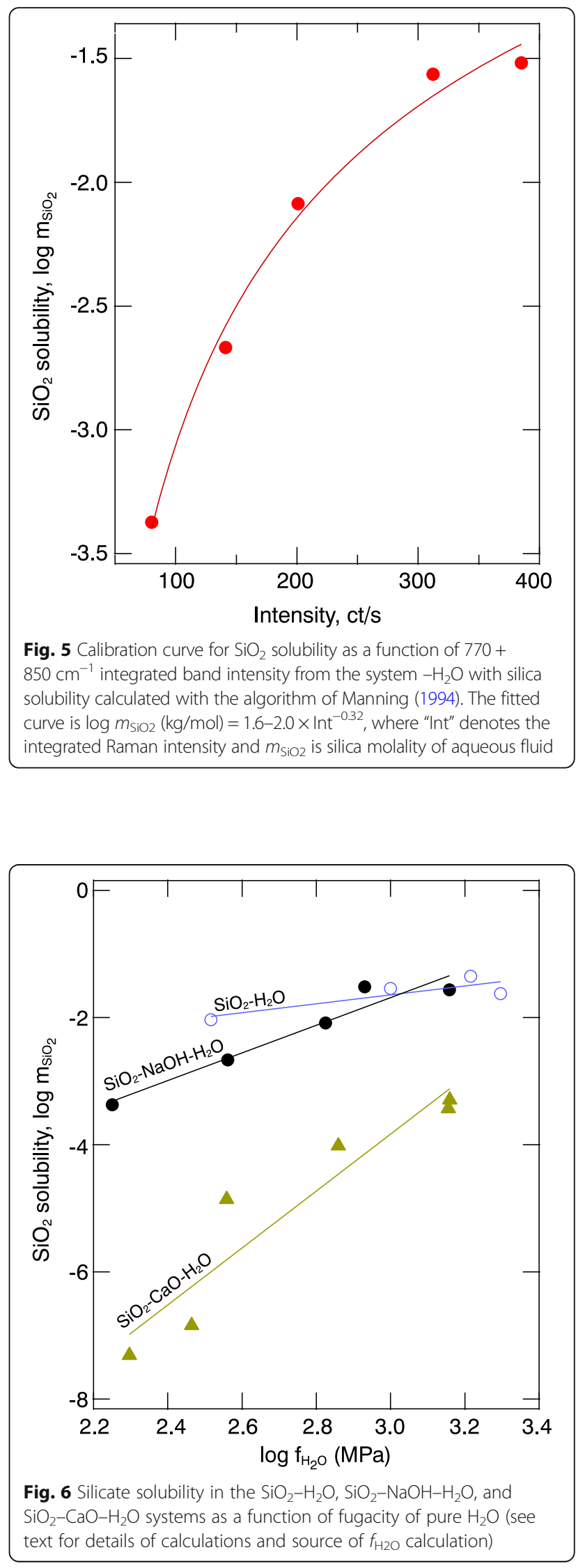
simpler $\mathrm{SiO}_{2}-\mathrm{H}_{2} \mathrm{O}$ system. The solubility is, however, more sensitive to $f_{\mathrm{H} 2 \mathrm{O}}$ in the $\mathrm{SiO}_{2}-\mathrm{NaOH}-\mathrm{H}_{2} \mathrm{O}$ system so that at high $\mathrm{H}_{2} \mathrm{O}$ fugacity, the $\mathrm{SiO}_{2}$ solubility in the $\mathrm{SiO}_{2}-\mathrm{NaOH}-\mathrm{H}_{2} \mathrm{O}$ system exceeds that in $\mathrm{SiO}_{2}-\mathrm{H}_{2} \mathrm{O}$ fluids (Fig. 6). The temperature/pressure coordinates of the solubility cross-over $\left(750-800{ }^{\circ} \mathrm{C}\right.$ at $\left.\sim 900 \mathrm{MPa}\right)$, from linear extrapolation of the curves in Fig. 6, occur at the conditions just below the second critical point in the $\mathrm{SiO}_{2}-\mathrm{H}_{2} \mathrm{O}$ system at $1080{ }^{\circ} \mathrm{C}$ and $970 \mathrm{MPa}$ (Kennedy et al. 1962). In contrast, linear extrapolation of the $\mathrm{SiO}_{2}-\mathrm{CaO}-\mathrm{H}_{2} \mathrm{O}$ line leads to a cross-over at an $f_{\mathrm{H} 2 \mathrm{O}}$ corresponding to $\sim 1300 \mathrm{MPa}$ pressure at $800{ }^{\circ} \mathrm{C}$. These pressure and temperature conditions are inside the supercritical region of the $\mathrm{SiO}_{2}-\mathrm{H}_{2} \mathrm{O}$ system, which means that conditions of greater silica solubility in $\mathrm{SiO}_{2}-\mathrm{CaO}-\mathrm{H}_{2} \mathrm{O}$ fluids than in $\mathrm{SiO}_{2}-\mathrm{H}_{2} \mathrm{O}$ and $\mathrm{SiO}_{2}-\mathrm{NaOH}-\mathrm{H}_{2} \mathrm{O}$ cannot be realized.

\section{Silicate speciation in fluid}

The approximate concentration of the silicate species in fluid ( $\mathrm{Q}^{n}$ species) can be obtained from the integrated intensities of the 770 and $850 \mathrm{~cm}^{-1}$ bands of the Raman spectra of fluid. The concentrations thus obtained depend, however, on the assumption that the relative intensities of these two Raman bands are equal to the mol fraction of the species. Given the similar $\mathrm{Si}-\mathrm{O}^{-}$force constants for $\mathrm{Si}-\mathrm{O}^{-}$stretch vibrations in $\mathrm{Q}^{0}$ and $\mathrm{Q}^{1}$ in hydrous melts (Cody et al. 2005), the equivalence of relative intensities of the 770 and $850 \mathrm{~cm}^{-1}$ bands and the mol fraction of $\mathrm{Q}^{0}$ and $\mathrm{Q}^{1}$ species seems a reasonable assumption.

In the $\mathrm{SiO}_{2}-\mathrm{H}_{2} \mathrm{O}$ and $\mathrm{SiO}_{2}-\mathrm{NaOH}-\mathrm{H}_{2} \mathrm{O}$ systems, silica-saturated fluids contain both $\mathrm{Q}^{1}$ and $\mathrm{Q}^{0}$ species, whereas in the $\mathrm{SiO}_{2}-\mathrm{CaO}-\mathrm{H}_{2} \mathrm{O}$ system, only $\mathrm{Q}^{0}$ species were detected in the temperature and pressure range. For the $\mathrm{SiO}_{2}-\mathrm{H}_{2} \mathrm{O}$ and $\mathrm{SiO}_{2}-\mathrm{NaOH}-\mathrm{H}_{2} \mathrm{O}$ fluids, the $\mathrm{Q}^{0}$ abundance decreases with increasing temperature and pressure although this decrease is more pronounced in the $\mathrm{SiO}_{2}-\mathrm{NaOH}-\mathrm{H}_{2} \mathrm{O}$ system. This decrease is coupled with increasing $\mathrm{Q}^{1}$ abundance. The rate of change of the abundance ratio, $X_{\mathrm{Q} 1} / X_{\mathrm{Q} 0}$, with temperature and pressure is considerably faster in the $\mathrm{SiO}_{2}-\mathrm{NaOH}-\mathrm{H}_{2} \mathrm{O}$ system and, in fact, can be expressed as linear functions of $\mathrm{SiO}_{2}$ molality, $m_{\mathrm{SiO} 2}$ (Fig. 7). Qualitatively, this behavior resembles that for $\mathrm{SiO}_{2}-\mathrm{H}_{2} \mathrm{O}$ and $\mathrm{SiO}_{2}-\mathrm{MgO}-\mathrm{H}_{2} \mathrm{O}$ fluids at pressures above $2 \mathrm{GPa}$ (Mysen et al. 2013). This behavior also is qualitatively similar to that of increased silicate polymerization with increasing total $\mathrm{SiO}_{2}$ concentration in silicate melts (Buckermann et al. 1992). The difference in silicate species abundance between $\mathrm{SiO}_{2}-\mathrm{H}_{2} \mathrm{O}$ and $\mathrm{SiO}_{2}-$ $\mathrm{NaOH}-\mathrm{H}_{2} \mathrm{O}$ fluids probably occurs because steric hindrance associated with nonbridging oxygen (NBO) bonding to $\mathrm{H}^{+}$is greater than $\mathrm{Na}^{+}-\mathrm{NBO}$ bonding given the much smaller ionic radius of $\mathrm{H}^{+}$. Protons will, therefore,

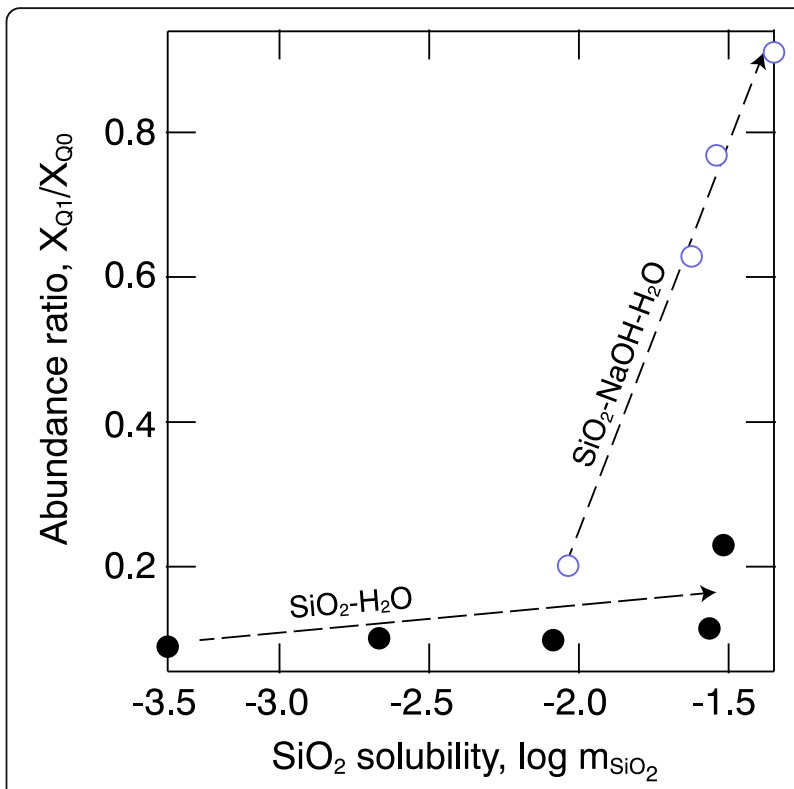

Fig. 7 Silicate species abundance ratio, $X_{Q_{1} / X_{\mathrm{Q} 0}}(X=$ mol fraction) as a function of $\mathrm{SiO}_{2}$ solubility $(\mathrm{kg} / \mathrm{mol})$

favor nonbridging oxygen in $\mathrm{Q}^{0}$ species, whereas $\mathrm{Na}^{+}$will form bonding with nonbridging oxygen in $\mathrm{Q}^{1}$ species. Hence, the more rapid increase in $X_{\mathrm{Q} 1} / X_{\mathrm{Q} 0}$ in the $\mathrm{SiO}_{2}-$ $\mathrm{NaOH}-\mathrm{H}_{2} \mathrm{O}$ systems than in $\mathrm{SiO}_{2}-\mathrm{H}_{2} \mathrm{O}$.

\section{Thermodynamic considerations}

When $\mathrm{Q}^{0}$ and $\mathrm{Q}^{1}$ species are present in the fluid, the equilibrium is:

$$
2 \mathrm{Q}^{0} \Leftrightarrow \mathrm{Q}^{1}
$$

with the equilibrium constant:

$$
K_{(2)}=X_{\mathrm{Q} 1} /\left(X_{\mathrm{Q} 0}\right)^{2},
$$

where $X_{\mathrm{Q} 1}$ and $X_{\mathrm{Q} 0}$ are mol fractions of $\mathrm{Q}^{1}$ and $\mathrm{Q}^{0}$, respectively. This equilibrium applies to the $\mathrm{SiO}_{2}-\mathrm{H}_{2} \mathrm{O}$ and $\mathrm{SiO}_{2}-\mathrm{NaOH}-\mathrm{H}_{2} \mathrm{O}$ fluids in the temperature and pressure range discussed here. We note that it differs from that of $\mathrm{SiO}_{2}-\mathrm{H}_{2} \mathrm{O}$ at higher pressures (1.8$5.2 \mathrm{GPa})$ where the silica concentration is sufficiently high to stabilize even more polymerized $\mathrm{Q}^{2}$ species as well (Mysen et al. 2013).

The silicate speciation in the $\mathrm{SiO}_{2}-\mathrm{CaO}-\mathrm{H}_{2} \mathrm{O}$ fluids is simpler than in the other two systems as the only species throughout the temperature and pressure is $\mathrm{Q}^{0}$ only (Fig. 4). Under such circumstances, the 
equilibrium constant equals concentration in the fluid, $m_{\mathrm{SiO} 2}$ :

$$
K=m_{\mathrm{SiO} 2}
$$

From the temperature dependence of the equilibrium constants, the enthalpy change of the reactions follows from:

$$
\ln K=-\Delta H / R T+\Delta S / R
$$

where $\Delta H$ and $\Delta S$ are the enthalpy and entropy changes, $T$ is absolute temperature, and $R$ is the gas constant. It is assumed in using this equation that there is no pressure effect on the equilibria in the pressure range of these experimental results (Table 1). This conclusion is substantiated by the $\mathrm{SiO}_{2}-\mathrm{H}_{2} \mathrm{O}$ and $\mathrm{SiO}_{2}-\mathrm{MgO}-\mathrm{H}_{2} \mathrm{O}$ fluid data of Mysen et al. (2013) who did not detect a pressure dependence in the same pressure range as the present experiments.

A linear fit to $\ln K$ versus $1 / T$ yields significantly different $\Delta H$ values for the equilibria among the $\mathrm{Q}^{n}$ species in the fluid (Fig. 8). For the $\mathrm{SiO}_{2}-\mathrm{CaO}-\mathrm{H}_{2} \mathrm{O}$ system (Fig. 8a), equilibrium (4) describes the situation. It is more sensitive to temperature $(\Delta H=322 \pm 4 \mathrm{~kJ} / \mathrm{mol})$ than equilibrium (2), which describes the speciation variations in the $\mathrm{SiO}_{2}-\mathrm{H}_{2} \mathrm{O}(22 \pm 12 \mathrm{~kJ} / \mathrm{mol})$ and $\mathrm{SiO}_{2}-\mathrm{NaOH}-\mathrm{H}_{2} \mathrm{O}$ systems (51 $\pm 17 \mathrm{~kJ} / \mathrm{mol}$; see Fig. 8).

\section{Conclusions}

Silicate speciation in silica-saturated aqueous fluids suggested from thermodynamic modeling indicates that species more polymerized than $\mathrm{Si}(\mathrm{OH})_{4}$ type exist in aqueous fluids under pressure/temperature conditions relevant to upper mantle processes (Newton and Manning 2003). This suggestion is consistent with the structural observations reported here and elsewhere (Zotov and Keppler 2002; Mysen et al. 2013). We also note, however, that when $\mathrm{NaOH}$ instead of $\mathrm{CaO}$ is the third component added to $\mathrm{SiO}_{2}-\mathrm{H}_{2} \mathrm{O}$, the silicate solubility is higher, and both $\mathrm{Q}^{0}$ and $\mathrm{Q}^{1}$ species occur in the $\mathrm{SiO}_{2}-\mathrm{NaOH}-\mathrm{H}_{2} \mathrm{O}$ fluids at lower pressures than in the alkaline earth systems. We note, though, that in these experiments $\mathrm{Na}^{+}$was added as an $\mathrm{NaOH}+\mathrm{H}_{2} \mathrm{O}$ solution. We cannot rule out a contribution to the silicate solubility from the alkaline nature of the fluid such as, for example:

$$
2 \mathrm{Q}^{n}+2 \mathrm{Na}^{+}+2 \mathrm{OH}^{-}=2 \mathrm{Q}^{n-1}+\mathrm{H}_{2} \mathrm{O},
$$

where, therefore, $\mathrm{pH}$ would be a contributing factor to the silicate solubility.

Furthermore, as the silicate concentration in aqueous fluids increases and silicate species becomes more polymerized with pressure and temperature, the types and abundance $\mathrm{Q}^{n}$ species more closely resemble those in hydrous silicate melts (Zotov and Keppler 1998; Cody et al. 2005; Mysen 2010). This structural evolution may lead to complete miscibility between silicate and aqueous fluid. It is likely that complete miscibility between fluid and melt occurs at lower pressure in alkali silicate systems than in those of alkaline earth silicate systems because of the greater silicate solubility in alkali silicate fluids. This conclusion accords with experimental observations that show complete miscibility near 1-1.5 GPa in alkali silicate and aluminosilicate systems, whereas pressure exceeds $3 \mathrm{GPa}$ before reaching miscibility in alkaline earth systems (Bureau and Keppler 1999; Stalder et al. 2001; Mibe et al. 2007).

Experimental data indicate that solubility of geochemically important minor and trace elements in aqueous fluids can be significantly affected by other silicate components (Manning 2007; Mysen 2012a, b). This happens because the stability and concentration of minor and trace element complexes (oxy complexes) in fluids depend on the electronic properties of cations available for this purpose in the fluid (Mysen 2012b, 2015b). This means that when considering partitioning of such elements between
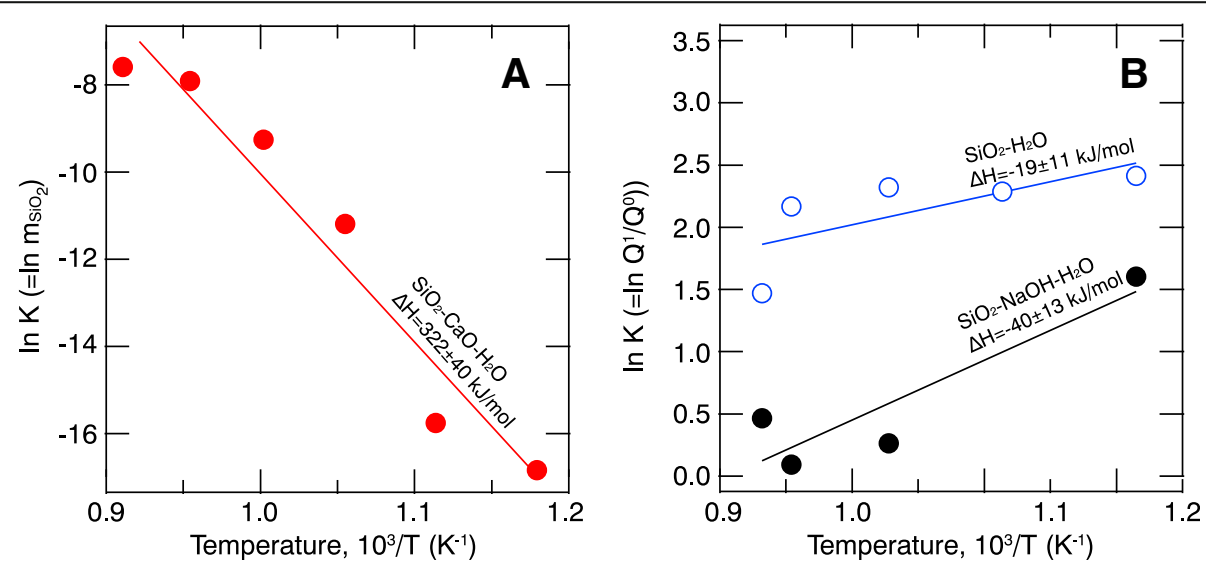

Fig. 8 Equilibrium constants for reactions (4) (a) and (2) (b) as a function of temperature. The $\Delta H$ values are from least squares fit to Eq. (3) 
minerals and aqueous fluids in the upper mantle and deep crust, pressure-dependent partition coefficients likely reflect changing silicate-cation interaction in the fluid as a function of silicate solubility and speciation.

Qualitatively, this behavior also means that for fluids in equilibrium with mafic and ultramafic mineral assemblages where alkaline earths are dominating cations, the silicate solubility in fluid is less and silicate polymerization is less extensive than in fluids in the equilibrium in felsic systems such as typical gneiss compositions, for example, where alkali metals are more important. Moreover, because the fluid composition in equilibrium with such different crystalline rocks differs, minor and trace element complexing in those different fluids also differs, which leads to different fluid-melt-crystal partition coefficients as a function of rock type (mineral assemblage) with which aqueous fluids equilibrated.

\section{Abbreviations}

$\Delta H$ : Enthalpy change; $\triangle S$ : Entropy change; CCD: Charge-coupled detector; $f_{\mathrm{H} 2 \mathrm{O}}: \mathrm{H}_{2} \mathrm{O}$ fugacity; HDAC: Hydrothermal diamond anvil cell; HFSE: High field strength element; $m_{\mathrm{SiO} 2}: \mathrm{SiO}_{2}$ molality; $R$ : Gas constant; $X_{\mathrm{QO}}$ : Mol fraction of $Q^{0}$ species; $X_{Q 1}$ : Mol fraction of $Q^{1}$ species

\section{Acknowledgements}

Instrument, electronics, and library support was provided by Geophysical Laboratory technical staff. Their support is gratefully acknowledged.

\section{Funding}

This research was supported by grant EAR1212854 from the National Science Foundation.

\section{Availability of data and materials}

The data used are reported in the manuscript tables. All original data are available from the author on request.

\section{Authors' contributions}

All research reported in this report was carried out by the author. The author read and approved the final manuscript.

\section{Competing interests}

The author declares that he has no competing interests.

\section{Publisher's Note}

Springer Nature remains neutral with regard to jurisdictional claims in published maps and institutional affiliations.

Received: 16 May 2018 Accepted: 19 July 2018

Published online: 14 August 2018

\section{References}

Bassett WA, Shen AH, Bucknum M, Chou IM (1993) A new diamond cell for hydrothermal studies to $2.5 \mathrm{GPa}$ and from $-190^{\circ} \mathrm{C}$ to $1200^{\circ} \mathrm{C}$. Rev Sci Instrum 64:2340-2345. https://doi.org/10.1063/1.1143931

Brawer SA, White WB (1975) Raman spectroscopic investigation of the structure of silicate glasses. I. The binary silicate glasses. J Chem Phys 63:2421-2432. https://doi.org/10.1063/1.431671

Buckermann WA, Muller-Warmuth W, Frischat GH (1992) A further 29Si MAS NMR study on binary alkali silicate glasses. Glasstech Ber 65:18-21

Burchard M, Maresch WW, Fockenberg T, Doltsinis NL, Adeagbo WA (2011) Modelling high-pressure aqueous fluids in the system $\mathrm{CaO}^{-} \mathrm{SiO}_{2}-\mathrm{H}_{2} \mathrm{O}$ : a comprehensive semi-empirical thermodynamic formalism. Eur J Mineral 23: 409-424. https://doi.org/10.1127/0935-1221/2011/0023-2106

Bureau H, Keppler H (1999) Complete miscibility between silicate melts and hydrous fluids in the upper mantle; experimental evidence and geochemical implications. Earth Planet Sci Lett 165:187-196. https://doi.org/10.1016/ S0012-821X(98)00266-0

Cody GD, Mysen BO, Lee SK (2005) Structure vs. composition: a solid-state $\mathrm{H}-1$ and $\mathrm{Si}-29 \mathrm{NMR}$ study of quenched glasses along the $\mathrm{Na}_{2} \mathrm{O}-\mathrm{SiO}_{2}-\mathrm{H}_{2} \mathrm{O}$ join. Geochim Cosmochim Acta 69:2373-2384. https://doi.org/10.1016/j. gca.2004.11.012

Fockenberg T, Burchard M, Maresch WW (2006) Experimental determination of the solubility of natural wollastonite in pure water up to pressures of $5 \mathrm{GPa}$ and at temperatures of 400-800 degrees C. Geochim Cosmochim Acta 70: 1796-1806. https://doi.org/10.1016/j.gca.2005.12.017

Kawamoto T, Kanzaki M, Mibe K, Matsukage KN, Ono S (2012) Separation of supercritical slab-fluids to form aqueous fluid and melt components in subduction zone magmatism. Proc Natl Acad Sci USA 109:18695-18700. https://doi.org/10.1073/pnas.1207687109

Kennedy GC, Wasserburg GJ, Heard HC, Newton RC (1962) The upper threephase region in the system $\mathrm{SiO}_{2}-\mathrm{H}_{2} \mathrm{O}$. Am J Sci 260:501-521. https://doi.org/ 10.2475/ais.260.7.501

Kessel R, Schmidt MW, Ulmer P, Pettke T (2005) Trace element signature of subduction-zone fluids, melts and supercritical liquids at 120-180 km depth. Nature 437:724-727. https://doi.org/10.1038/nature03971

Kessel R, Ulmer P, Pettke T, Schmidt MW, Thompson AB (2004) A novel approach to determine high-pressure high-temperature fluid and melt compositions using diamond-trap experiments. Am Mineral 89:1078-1086

Manning CE (1994) The solubility of quartz in $\mathrm{H}_{2} \mathrm{O}$ in the lower crust and upper mantle. Geochim Cosmochim Acta 58:4831-4840. https://doi.org/10.1016/ 0016-7037(94)90214-3

Manning CE (2004) The chemistry of subduction-zone fluids. Earth Planet Sci Lett 223:1-16. https://doi.org/10.1016/j.epsl.2004.04.030

Manning CE (2007) Solubility of corundum+kyanite in $\mathrm{H}_{2} \mathrm{O}$ at $700^{\circ} \mathrm{C}$ and $10 \mathrm{kbar}$ : evidence for Al-Si complexing at high pressure and temperature. Geofluids 7 : 258-268. https://doi.org/10.1111/j.1468-8123.2007.00179.x

Manning CE, Boettcher S (1994) Rapid quench hydrothermal experiments at mantle pressures and temperatures. Am Mineral 79:1153-1158

McMillan PF, Wolf GH, Poe BT (1992) Vibrational spectroscopy of silicate liquids and glasses. Chem Geol 96:351-366. https://doi.org/10.1016/00092541(92)90064-C

Mibe K, Chou IM, Bassett WA (2008) In situ Raman spectroscopic investigation of the structure of subduction-zone fluids. J Geophys Res 113. https://doi.org/ 10.1029/2007jb005179

Mibe K, Kanzaki M, Kawamoto T, Matsukage KN, Fei Y, Ono S (2007) Second critical endpoint in the peridotite- $\mathrm{H}_{2} \mathrm{O}$ system. J Geophys Res 112. https:// doi.org/10.1029/2005JB004125

Mibe, K., Kawamoto, T., Matsukage, K.N., Fei, Y., and Ono, S. (2011) Slab melting versus slab dehydration in subduction-zone magmatism. Proc. Nat'l. Acad. Sci. https://doi.org/10.1073/pnas.1010968108

Mysen $\mathrm{BO}$ (2010) Structure of $\mathrm{H}_{2} \mathrm{O}$-saturated peralkaline aluminosilicate melt and coexisting aluminosilicate-saturated aqueous fluid determined in-situ to 800 C and $800 \mathrm{MPa}$. Geochim Cosmochim Acta 74:4123-4139. https://doi.org/10. 1016/j.gca.2010.04.024

Mysen BO (2012a) Silicate-COH melt and fluid structure, their physicochemical properties, and partitioning of nominally refractory oxides between melts and fluids. Lithos 148:228-246. https://doi.org/10.1016/j.lithos.2012.06.005

Mysen BO (2012b) High-pressure/-temperature titanium solution mechanisms in silicate-saturated aqueous fluids and hydrous silicate melts. Am Mineral 97: 1241-1251. https://doi.org/10.2138/am.2012.4084

Mysen BO (2015a) Carbon speciation in silicate-C-O-H as a function of redox conditions: an experimental study, in-situ to $1.7 \mathrm{GPa}$ and $900^{\circ} \mathrm{C}$. Am Mineral 100:872-882. https://doi.org/10.2138/am-2015-4976

Mysen BO (2015b) An in-situ experimental study of $\mathrm{Zr}^{4+}$ transport capacity of water-rich fluids in the temperature and pressure range of the deep crust and upper mantle. Prog Earth Planet Sci 2(1):38. https://doi.org/10.1186/ s40645-015-0070-5

Mysen BO, Mibe K, Chou IM, Bassett WA (2013) Structure and equilibria among silicate species in aqueous fluids in the upper mantle: experimental $\mathrm{SiO}_{2}-\mathrm{H}_{2} \mathrm{O}$ and $\mathrm{MgO}-\mathrm{SiO}_{2}-\mathrm{H}_{2} \mathrm{O}$ data recorded in situ to 900 degrees $\mathrm{C}$ and 5.4GPa. J Geophys Res 118:6076-6085. https://doi.org/10.1002/2013jb010537

Mysen BO, Richet P (2005) Silicate glasses and melts - properties and structure. Elsevier, New York, p 548

Mysen BO, Yamashita S (2010) Speciation of reduced C-O-H volatiles in coexisting fluids and silicate melts determined in-situ to $\sim 1.4 \mathrm{GPa}$ and $800^{\circ} \mathrm{C}$. Geochim Cosmochim Acta 74:4577-4588 
Newton RC, Manning CE (2002) Solubility of enstatite+forsterite in $\mathrm{H}_{2} \mathrm{O}$ in deep crust/upper mantle conditions: 4 to $15 \mathrm{kbar}$ and 700 to $900^{\circ} \mathrm{C}$. Geochim Cosmochim Acta 66:4165-4176. https://doi.org/10.1016/S0016-7037(02)00998-5 Newton RC, Manning CE (2003) Activity coefficient and polymerization of aqueous silica at $800^{\circ} \mathrm{C}, 12 \mathrm{kbar}$, from solubility measurements and $\mathrm{SiO}_{2}{ }^{-}$ buffering mineral assemblages. Contrib Mineral Petrol 146:135-146. https:// doi.org/10.1007/s00410-003-0483-9

Newton RC, Manning CE (2009) Hydration state and activity of aqueous silica in $\mathrm{H}_{2} \mathrm{O}-\mathrm{CO}_{2}$ fluids at high pressure and temperature. Am Mineral 94:1287-1290. https://doi.org/10.2138/am.2009.3287

Osborn EF, Muan A (1960) Plate 2. The system $\mathrm{CaO}-\mathrm{MgO}_{\mathrm{SiO}}$ : phase equilibrium diagrams of oxide systems. American Ceramic Society

Pitzer KS, Sterner SM (1994) Equations of state valid continuously from zero to extreme pressures for $\mathrm{H}_{2} \mathrm{O}$ and $\mathrm{CO}_{2}$. J Chem Phys 101:3111-3116. https://doi. org/10.1063/1.467624

Ratcliffe Cl, Irish DE (1982) Vibrational studies of solutions at elevated temperatures and pressures. 5. Raman studies of liquid water up to $300{ }^{\circ} \mathrm{C}$. J Phys Chem 86:4897-4905. https://doi.org/10.1021/j100222a013

Stalder R, Ulmer P, Thompson AB, Gunther D (2001) High pressure fluids in the system $\mathrm{MgO}-\mathrm{SiO}_{2}-\mathrm{H}_{2} \mathrm{O}$ under upper mantle conditions. Contrib Mineral Petrol 140:607-618. https://doi.org/10.1007/s004100000212

Walrafen GE, Fisher MR, Hokmabadi MS, Yang WH (1986) Temperature dependence of the low- and high-frequency Raman scattering from liquid water. J Chem Phys 85:6970-6982. https://doi.org/10.1063/1.451384

Wilke M, Schmidt C, Dubrail J, Appel K, Borchert M, Kvashnina K, Manning CE (2012) Zircon solubility and zircon complexation in $\mathrm{H}_{2} \mathrm{O}+\mathrm{Na}_{2} \mathrm{O}+\mathrm{SiO}_{2} \pm \mathrm{Al}_{2} \mathrm{O}_{3}$ fluids at high pressure and temperature. Earth Planet Sci Lett 349-350:15-25. https://doi.org/10.1016/j.epsl.2012.06.054

Zhang Y-G, Frantz JD (2000) Enstatite-forsterite-water equilibria at elevated temperatures and pressures. Am Mineral 85:918-925. https://doi.org/10.2138/ am-2000-0705

Zotov N, Keppler H (1998) The influence of water on the structure of hydrous sodium tetrasilicate glasses. Am Mineral 83:823-834

Zotov N, Keppler H (2002) Silica speciation in aqueous fluids at high pressures and high temperatures. Chem Geol 184:71-82. https://doi.org/10.1016/50009$2541(01) 00353-9$

\section{Submit your manuscript to a SpringerOpen ${ }^{\circ}$ journal and benefit from:}

- Convenient online submission

- Rigorous peer review

- Open access: articles freely available online

- High visibility within the field

- Retaining the copyright to your article

Submit your next manuscript at $\boldsymbol{\nabla}$ springeropen.com 